UNITED STATES

USGS-OFR--82-98

DEPARTMENT OF THE INTERIOR

GEOLOGICAL SURVEY

CHEMICAL AND ISOTOPIC COMPOSITION OF WATER FROM THERMAL

AND MINERAL SPRINGS OF WASHINGTON

By R. H. Mariner, T. S. Presser, and W. C. Evans

Open-File Report 82-98

Menlo Park, California

February 1982

\section{NOTICE}

PORTIONS OF THIS REPORT ARE ILLECIBLE:"

it has been reproduced from the best available copy to permit the brạadest possible availability.

\section{DE84 900474}




\section{DISCLAIMER}

This report was prepared as an account of work sponsored by an agency of the United States Government. Neither the United States Government nor any agency Thereof, nor any of their employees, makes any warranty, express or implied, or assumes any legal liability or responsibility for the accuracy, completeness, or usefulness of any information, apparatus, product, or process disclosed, or represents that its use would not infringe privately owned rights. Reference herein to any specific commercial product, process, or service by trade name, trademark, manufacturer, or otherwise does not necessarily constitute or imply its endorsement, recommendation, or favoring by the United States Government or any agency thereof. The views and opinions of authors expressed herein do not necessarily state or reflect those of the United States Government or any agency thereof. 


\section{DISCLAIMER}

Portions of this document may be illegible in electronic image products. Images are produced from the best available original document. 
Abstract-1-2.-

Introduction-_...-

Methods and Procedures-_-

Chemical Compositions-a

Geothermometry-_an

Discussion-

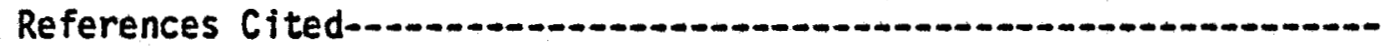

\section{1}

1

\section{ILLUSTRATIONS}

Figure 1. Map of the State of Washington showing the location of sampled thermal and mineral springs..........

Figure 2. Physiographic divisions of Washington

TABLES

Page

Table 1. Chemical composition for the thermal and mineral springs of Washington-

Table 2. Trace element chemical composition for the springs of Washington-_..._. 8

Table 3. Compositions of gases discharging from springs in

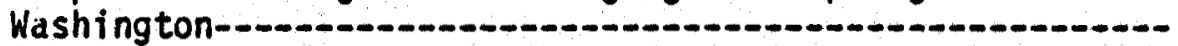

Table 4. Isotopic data for the springs of Washington-_.........

Table 5. Aquifer-temperature estimates for selected springs and wells in Washington 


\title{
CHEMICAL AND ISOTOPIC COMPOSITION OF WATER FROM THERMAL
} AND MINERAL SPRINGS OF WASHINGTON

By R. H. Mariner, T. S. Presser, and W. C. Evans

\begin{abstract}
Waters from the thermal springs of Washington range in chemical compositon from dilute $\mathrm{Na}-\mathrm{HCO}_{3}$ to moderately sal ine $\mathrm{CO}_{2}$-charged $\mathrm{Na}-\mathrm{HCO} 3-\mathrm{Cl}$ type waters. St. Martin's Hot Spring which discharges a slightly saline $\mathrm{Na}-\mathrm{Cl}$ water, is the notable exception. The dilute $\mathrm{Na}^{-} \mathrm{HCO}_{3}$ waters are generally associated with granitic intrusions; the warm to not $\mathrm{CO}_{2}$-charged waters issue on or near the large stratovolcanoes. The dilute waters have oxygen-isotopic compositions that indicate relatively 1 ittle water-rock exchange. The $\mathrm{CO}_{2}$-charged waters are usually more enriched in oxygen-18 due to more extensive water-rock reaction. The carbon-13 in the $\mathrm{CO}_{2}$-charged thermal waters is more depleted $(-10$ to $-12 \%)$ than in the cold $\mathrm{CO}_{2}$-charged soda springs $(-2$ to $-8 \%$ which are also scattered throughout the cascades. The hot and cold $\mathrm{CO}_{2}$-charged waters are supersaturated with respect to $\mathrm{CaCO}_{3}$, but only the hot springs are actively depositing $\mathrm{CaCO}_{3}$. Baker, Gamma, Sulphur, and Ohanapecosh hot springs seem to be associated with thermal aquifers of more than $100^{\circ} \mathrm{C}$. As these springs occur as individual springs or in small clusters, the respective aquifers are probably of restricted size.
\end{abstract}

\section{INTRODUCTION}

Berry and others (1980) 1 ist 23 thermal springs (greater than $20^{\circ} \mathrm{C}$ ) in Washington. Fumarole fields on Mount Baker, Mount St. Helens, Mount Adams, and Mount Rainier are included in their list along with two warm saline ponds, Hot Lake and Poison Lake in Okanogan County. The saline ponds are density stratified and owe their temperatures to heat from solar radiation trapped in the deeper saline layer. Most of the thermal springs in Washington issue near or just west of the crest of the Cascades (figures 1 and 2). The exceptions are the Warm Springs near Walla Walla, Simcoe Soda Springs, Klickitat Mineral Springs in the Columbia Basin, and Dlympic and Sol Duc hot springs in the 0lympic Mountains. Packwood, Collins, and Rock Creek hot springs were not sampled because they currently issue in rivers or creeks. Time constraints 
INITE: statks

DEPAKTMENT OF THE IMTEWIO

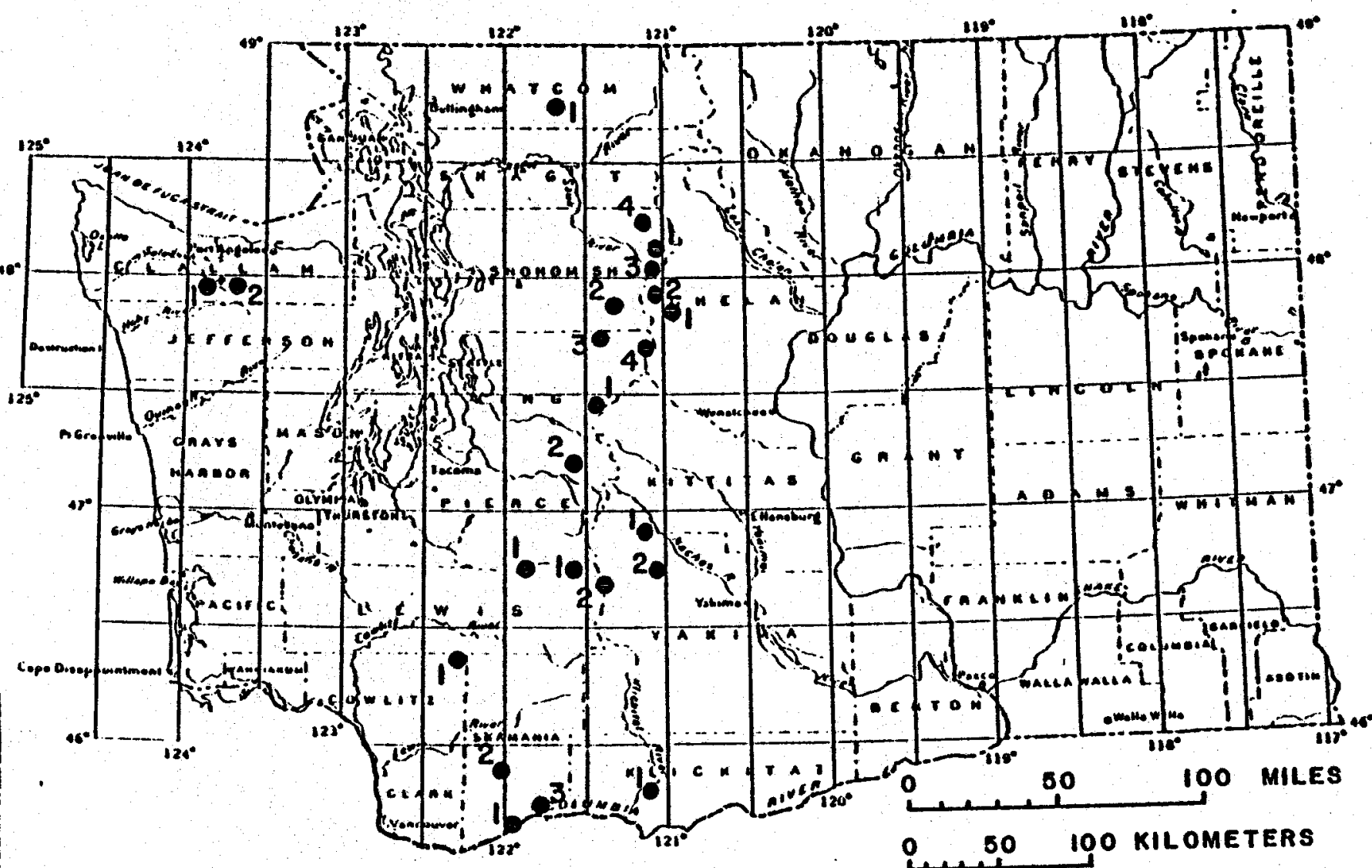

Figure 1. Map of the state of Washington showing the location of sampled thermal and mineral springs.
Chelan county

1. Little Wenatchee River Soda Spr.

2. Iittle Wenatchee ford Soda Spr. clallam county

1. Olympic Hot springs

2. Sol Duc Hot Springs cowlitz county

1. Green River soda Spr. King County

1. Goldmeyer Hot springs

2. Lester Hot Springs

3. Money Creek soda Spr.

4. Scentc Hot springs xilckitat county

1. Klickitat Springs Lewis county

1. Ohanapecosh Hot Springs

2. Surmit Creek Soda Spr. Pierce county

1. Longmire Mineral Springs Skamania County

1. Bonneville Hot Springs

2. Iron Mike

3. St. Martin's Hot Springs Snohomish county

1. Gama Hot Springs

2. Garland Mineral Springs

3. Kennedy Hot Springs

4. Sulphur Hot springs

Whatcom County

1. Baker Hot Spring

Yakima County

1. Bumping River Soda Spr.

2. Goose Egg Soda Spr. 


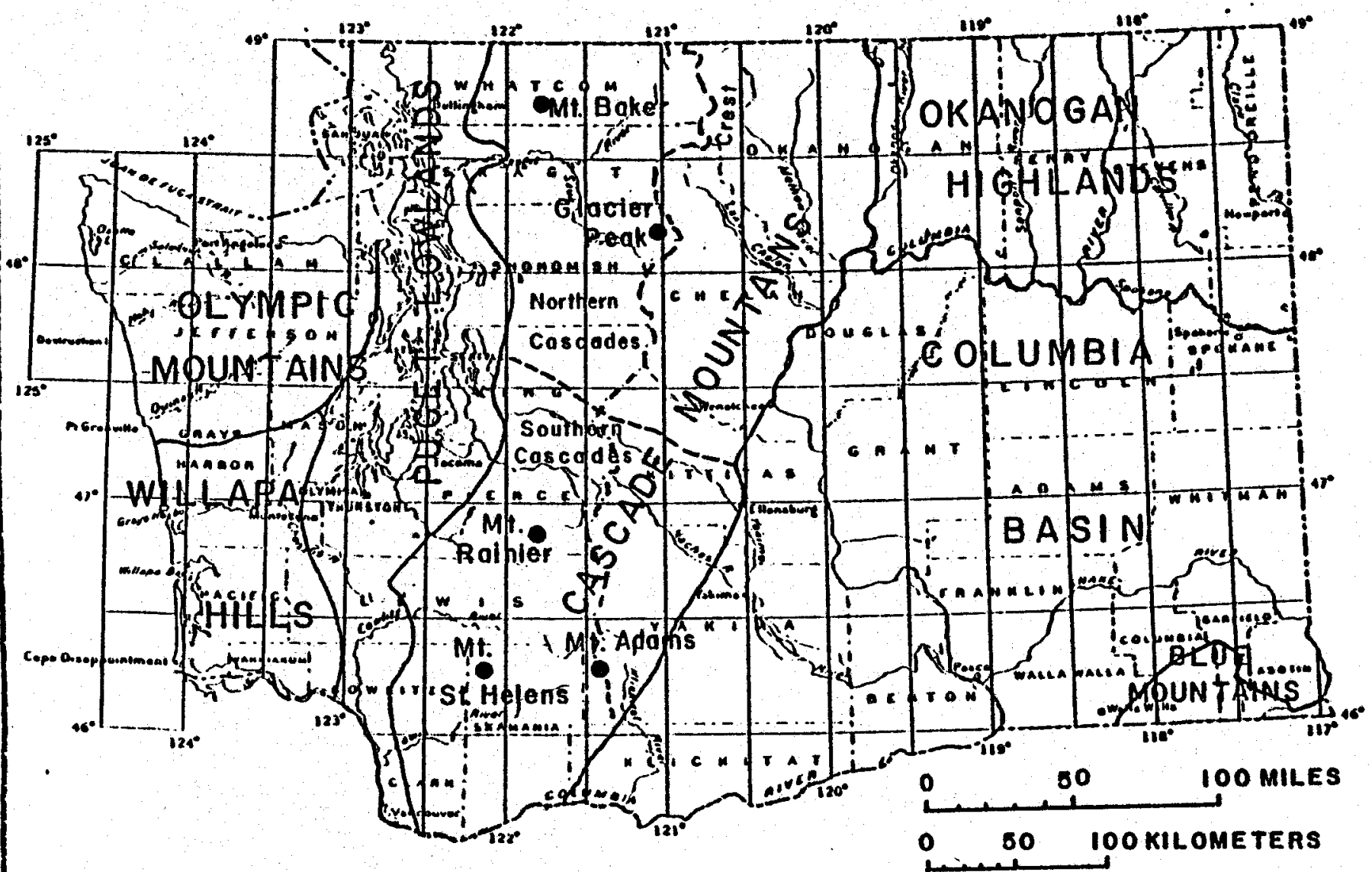

Figure 2. Physiographic divisions of Washington. 
did not allow us to sample Klickitat Mineral Springs $\left(27^{\circ} \mathrm{C}\right)$, Warm Springs Canyon Warm Springs $\left(22^{\circ} \mathrm{C}\right)$, Simcoe Soda Spring $\left(32^{\circ} \mathrm{C}\right)$, or Orr Creek Warm Springs $\left(22^{\circ} \mathrm{C}\right)$. Cool mineral springs, chiefly soda springs, are also scattered throughtout the Washington Cascades. Green River Soda Spring, west of Mount St. Helens, is reported to have a discharge temperature of $30^{\circ} \mathrm{C}$; however, temperatures of $16^{\circ} \mathrm{C}$ were measured in both April and July 1980. Earlier measurements may have been in error or the spring plumbing may have been changed by seismic activity. Recent chemical analyses for Klickitat Mineral Spring, Government Mineral Spring, and the soda spring on the Green River have been presented by Barnes and others (1981).

The Cascade Range, where most of the thermal and mineral springs occur, can be divided into two geologically different areas (Weissenborn and Cates, 1966). North of Snoqualmie Pass the range consists essentially of a core of granitic rock and metamorphosed sedimentary rocks flanked by younger sedimentary and volcanic rock. South of Snoqualimie Pass, Tertiary volcanic rock with relatively simple structure predominates. Superimposed on the range are the young volcanoes, Mount Adams, Mount Rainier, Mount Baker, Glacier Peak, and Mount St. Helens. The Olympic Mountains consist of a heterogenous metamorphic and plutonic basement complex composed of gneissic amphibolites and quartz diorite overlain by eugeosynclinal sedimentary and volcanic rocks (Wagner and Snavely, 1966). The Columbia Basin, an area of extensive flood basalts of Miocene and Pliocene age, occupies most of southeastern Washington (Grigys,1966).

None of the thermal springs discharge from or are associated with siliceous sinter, an indicator of high subsurface temperature. Ohanapecosh, Kennedy, Garland, and Longmire discharge from travertine mounds. Fossil travertine deposits occur at Gamma Hot Springs within a few feet of the current spring orifices. Gamma Hot Springs discharge in or immediately adjacent to a stream which probably erodes any $\mathrm{CaCO}_{3}$ that is currently deposited by the springs. of the cold soda springs sampled, only sumit Creek Soda Springs still discharge from a travertine mound, al though fossil travertine occurs near several other cold soda springs.

\section{METHODS AND PROCEDURES}

The methods of sample collection and field determination of $\mathrm{pH}$, alkalinity, sulfide, ammonia, and aluminum were described by Presser and Barnes (1974). About 2 liters of spring water were pressure filtered through 
a 0.1 micrometer $(\mu m)$ membrane fllter using compressed nitrogen as the pressure source. Filteres water samples were stored in plastic bottles that had been rinsed to remove contaminants prior to use. Samples collected for group I and II metals were acidified to pH 2 or less with concentrated hydrochloric acid. An appropriate amount of deionized water was used to dilute $25 \mathrm{~mL}$ of filtered sample to attain dissolved silica concentrations of from 20 to $50 \mathrm{mg} / \mathrm{L}$. Dilutions of $1: 2,1: 4$, or $1: 5$ were used. Water temperatures were determined with a thermistor probe or a maximum reading mercury-in-glass thermometer. The $\mathrm{pH}$ was determined directly in the spring. Alkalinity was determined immediately after the sample was withdrawn from the spring. Sulfide (total sulfide as $\mathrm{H}_{2} \mathrm{~S}$ ) was precipitated as zinc sulfide from the hot sample. Precipitated samples were stored for as much as 12 hours in a refrigerator before being titrated by the fodometric method. A water sample for ammonia analysis was allowed to $c 001$ to air temperature before sodium hydroxide was added to raise the $\mathrm{pH}$ to approximately 12 . The dissolved ammonia concentration was then measured with an ammonia-specific ion electrode. Water samples for aluminum were complexed with 8-hydroxyquinoline, buffered at pH 3.3, and extracted with methyl isobutyl ketone. Mercury was stabilized for later analysis in the laboratory by addition of 2:1 $\mathrm{H}_{2} \mathrm{SO}_{4}: \mathrm{HNO}_{3}, 5$ percent $\mathrm{KMnO}_{4}(\mathrm{w} / \mathrm{v})$, and 5 percent $\mathrm{K}_{2} \mathrm{~S}_{2} \mathrm{O}_{8}(\mathrm{w} / \mathrm{v})$.

Three samples of raw water were collected in $15 \mathrm{~mL}$ glass bottles with polyseal caps for stable-isotope analysis. Dissolved carbon dioxide species were precipitated in the field by adding $20 \mathrm{~mL}$ of saturated ammoniacal strontium chloride to approximately $100 \mathrm{~mL}$ of water from the spring. Samples of any gases escaping from the spring were collected in evacuated gas sample tubes.

Sodium, potassium, calcium, magnesium, lithium, rubidium, cesium, iron, manganese, zinc, and aluminum (field organic extract) concentrations were determined by direct aspiration on a double-beam atomic absorption spectrophotometer. Hethods for the analysis of boron, silica, and the anions were described in Skougstad and others (1979). Specifically the methods are: dianthrimide $(0.1$ to $1.0 \mathrm{mg} / \mathrm{L})$ and carmine $(1.0$ to $10 \mathrm{mg} / \mathrm{L})$ for boron; molybdate blue for silica; Mohr $(>12 \mathrm{mg} / \mathrm{L})$ for chloride; thorin for sulfate; specific ion electrode for fluoride; and hypochlorite oxidation for bromide and iodide. The ASTM (1974) ferric thiocyanide method was used for chioride concentrations $<10 \mathrm{mg} / \mathrm{L}$. Mercury was determined by a flameless atomic absorption technique (U.S. Environmental Protection Agency, 1971). These 
methods were modified to overcome interferences from iron hydroxide, calcite precipitates, and hydrogen sulfide.

Isotopic ratios of $180 / 160, \mathrm{D} / \mathrm{H}$ and ${ }^{13} \mathrm{C} /{ }^{12} \mathrm{C}$ were measured on a modified Nier double-collecting 6 -inch $60^{\circ}$ sector mass spectrometer. The metiods of sample preparations were: $\mathrm{CO}_{2}$-equilibration method of Cohn and Urey (1938) for oxygen; the uranium technique of Bigeleisen and others (1952) for hydrogen; and the phosphoric acid technique of McCrea (1950) for carbonates. Prior to analysis, the $\mathrm{SrCO}_{3}$ precipitate was filtered and washed under an argon atmosphere, dried, and homogenized in a ball mill.

Gases were analyzed by gas chromatography as soon as possible after returning to the laboratory, always within two weeks of collection. Linde Molecular Sieve $5 \mathrm{~A}^{1 /}$ was used to separate and quantify $\mathrm{He}, \mathrm{H}_{2}, \mathrm{O}_{2}, \mathrm{Ar}$, $\mathrm{N}_{2}$, and $\mathrm{CH}_{4}$, while Porapak Q $\underline{1 /}$ was used for $\mathrm{C}_{2} \mathrm{H}_{6}$ and $\mathrm{CO}_{2}$. Hel ium was used as the carrier gas except in the analysis for $\mathrm{He}$ and $\mathrm{H}_{2}$ where argon carrier was employed.

\section{CHEMICAL COMPOSITIONS}

The chemical composition of the thermal and mineral springs are given in tables 1 and 2. The waters may be classified as dilute $\mathrm{Na}_{-} \mathrm{HCO}_{3}, \mathrm{Na}-\mathrm{Cl}$, $\mathrm{Na}-\mathrm{HCO}_{3}-\mathrm{Cl}$, or $\mathrm{Na}-\mathrm{Ca}-\mathrm{HCO}_{3}-\mathrm{Cl}$ type waters. The dilute $\mathrm{Na}-\mathrm{HCO}_{3}$ waters include Olympic, Sol Duc, Goldmeyer, Lester, Scenic, and Bonneville hot springs. The $\mathrm{Na}-\mathrm{HCO}_{3}-\mathrm{Cl}$ waters are almost all $\mathrm{CO}_{2}$-charyed and include Baker, Gamma, Ohanapecosh, Garland, Kennedy, Goose Egg, Bumping River, Iron Mike, Longmire, Summit Creek, Little Wenatchee Ford, Little Wenatchee River, and Green River. Most of these $\mathrm{Na}_{-}-\mathrm{HCO}_{3}-\mathrm{Cl}$ waters are $\mathrm{CoOl}$ to cold; but Gamma, Ohanapecosh, Kennedy, and Garland have temperatures greater than $20^{\circ} \mathrm{C}$. These $\mathrm{CO}_{2}$-charged $\mathrm{Na}_{-} \mathrm{HCO}_{3}-\mathrm{Cl}$ waters have $\mathrm{pH}$ values of 6 to 6.5 and are slightly to moderately saline. Baker Hot Springs discharge the only dilute alkaline $\mathrm{Na}_{-} \mathrm{HCO}_{3}-\mathrm{Cl}$ water. St. Martin's Hot Springs discharge the only $\mathrm{Na}-\mathrm{Cl}$ thermal water in the state. Chemically, the water discharged from St. Martins Hot Springs is similar to the thermal springs that discharge in the Oregon Cascades (Mariner and others, 1980).

Gas discharge rates in the thermal and mineral springs range from slow and sporadic at Olympic, Sol Duc, and Goldmeyer, to rapid and nearly constant at

1/ The use of brand names is for identification purposes only and does not imply endorsement by the U.S. Geological Survey. 
Table 1. Chemical composition fur the thermal and aimeral springs of Mashington [Concentrations are in milligrams per liter]

Temperature pH Silica Calcium Magnesium Sodium Potasium Lithium Alkalinity Sulfate Chloride fluoride Boron Hydrogen

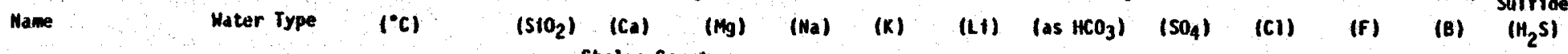

Soda S. L. Wenatchee R. $\mathrm{CO}_{2}$-charged Chelan County

Soda S. L. Mesatchee F. $\mathrm{CO}_{2}$-charged

$$
\begin{array}{llrll}
7 & 6.08 & 39 & 320 & 54
\end{array}
$$

$54 \quad 660 \quad 39$

Olympic Hot Springs

dllute $\mathrm{Na}-\mathrm{HCO}_{3}$

96.48 Clall am County

Sol Duc Mot Springs dilute $\mathrm{Na}-\mathrm{HCO}_{3}$

$48.5 \quad 9.50 \quad 66$

Sodd Sp. Green River $\mathrm{CO}_{2}$-charged

$51 \quad 9.46$

$\begin{array}{lll}9 & <.05 \quad & \end{array} 2$ Cowlitz County

Goldmeyer Hot Spring

Lester Hot Spring

dilute $\mathrm{Ha}-\mathrm{HCO}_{3}$ $16 \quad 6.49$

$97 \quad 225 \quad 92$

Scenic Hot Spring dilute $\mathrm{Ha}-\mathrm{HCO}_{3}$ King County -

Sodd Spring Money Creek $\mathrm{CO}_{2}$ gas discharge no water sample collected

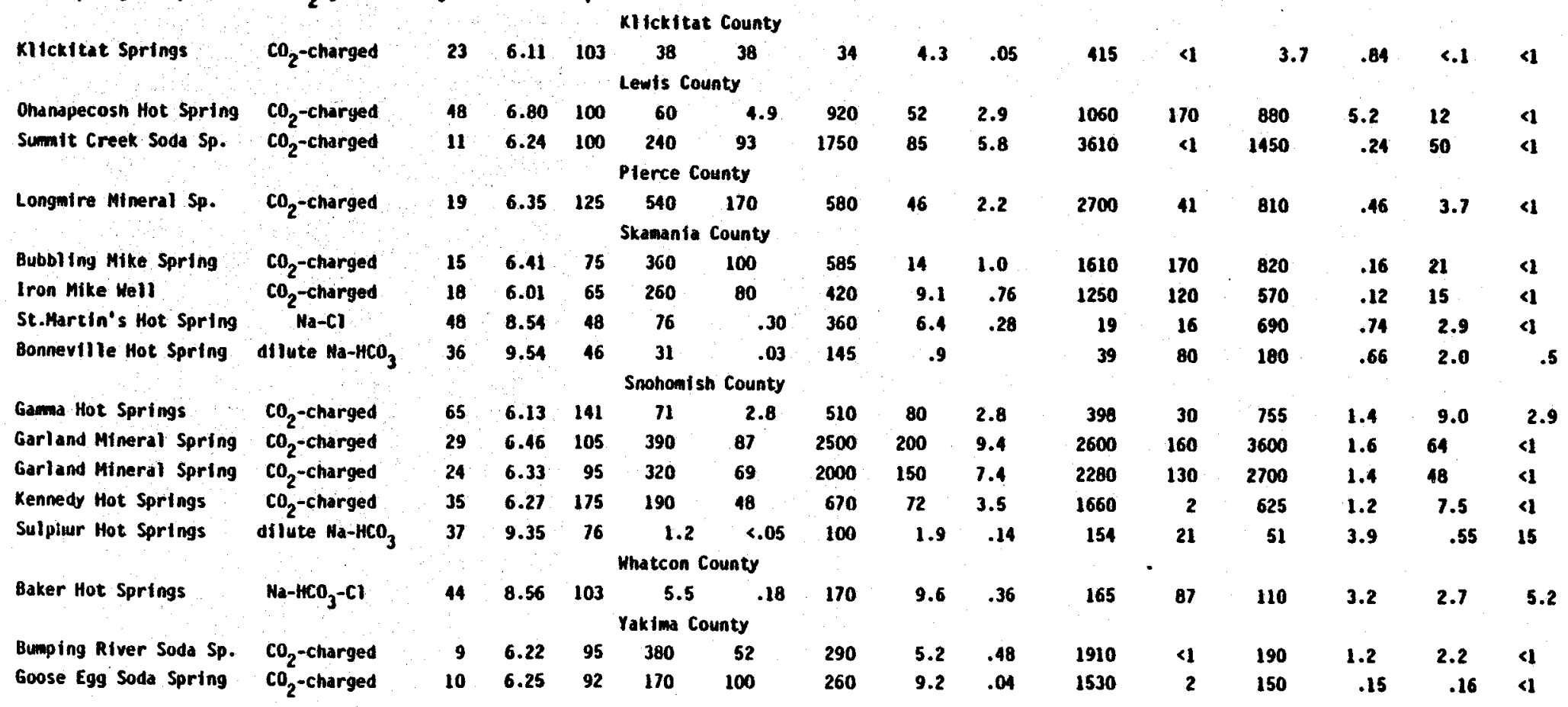


Table 2. Trace element chemical composition for the springs of Washington

Rubidtum Cestum Manganese Iron Amontum Bromide Aluminum Mercury Zinc
(Rb) (Cs) (Mn) (Fe) (as $N$ (B) (Br) (Al) (Hg) (Zn)
Chelan County

Soda Springs

Little Wenatchee $R$.

$0.24 \quad 11$

L. Wenatchee ford

Clallam County

Oiympic Hot Springs

$<0.02$

$<0.1<0.01<0.02$

1.7

3

Sol Duc Hot Springs

$<.02$

$<.1$

Cowlitz County

Soda spr. Green R.

$$
\text { King County }
$$

1
$1.1: 5$

1.25

10

10

42

Klickitat County

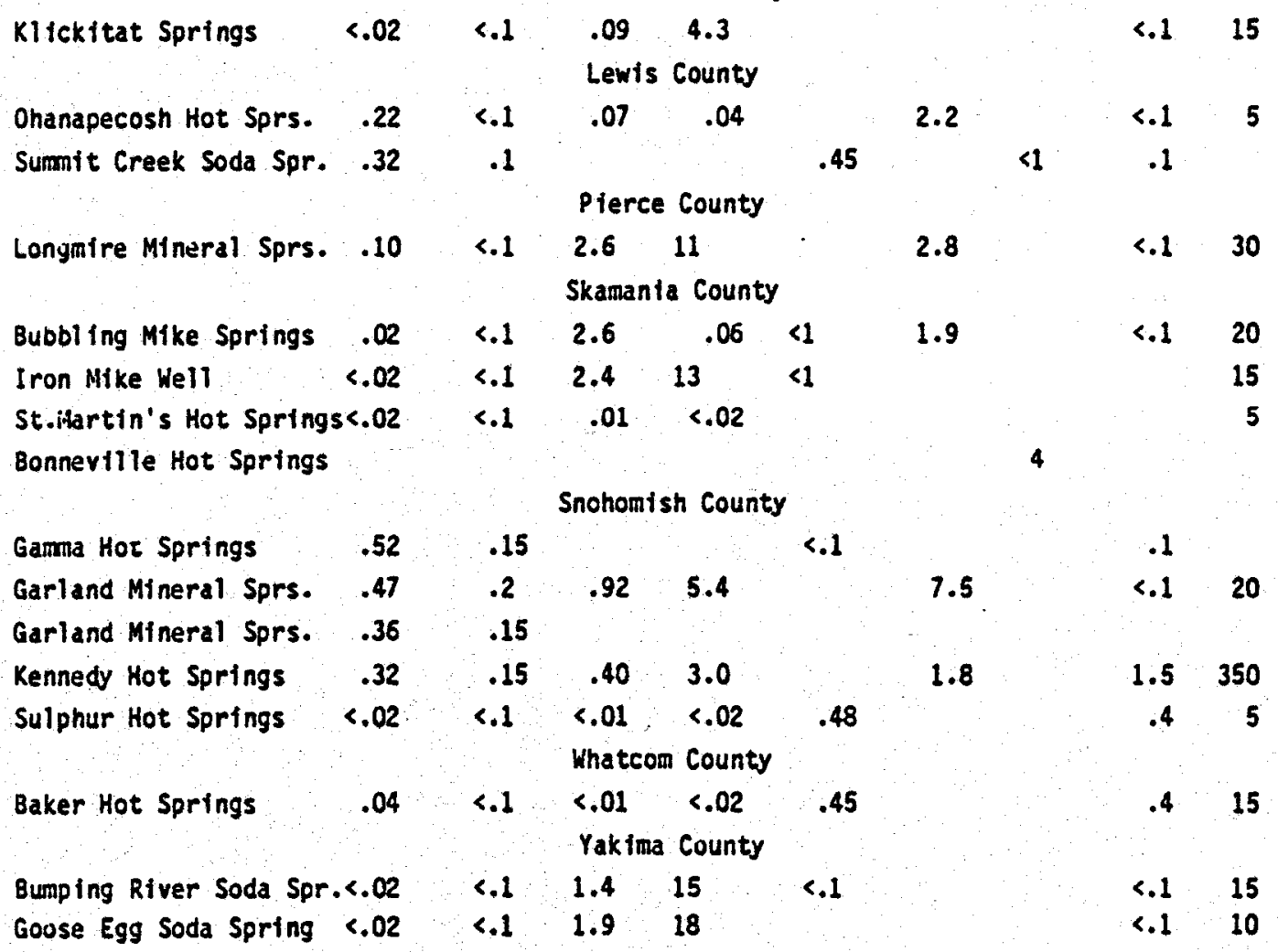


Ohanapecosh, Garland, Kennedy, Summit, Green River, Klickitat, Longmire, Bumping River, Goose Egg, Little Wenatchee River, and Little Wenatchee Ford. Springs with constant, rapid discharge rates discharge predominantly $\mathrm{CO}_{2}$; while springs with slow, sporadic discharge rates, discharge either nitrogen or nitrogen and methane (table 3 ).

Isotopic data for the thermal and mineral springs are given in table 4. $\mathrm{D} / \mathrm{H}$ values range from -78.8 to $-122.0 \%$ and $180 / 16_{0}$ values range from -7.37 to $-16.53 \%$. D/H values for cold springs immediately adjacent to several of the thermal springs are less depleted isotopicaly, indicating that the thermal springs recharge at higher elevations. Generally, the dilute waters have very small oxygen shifts $(<0.4 \%$ ) whereas the more saline waters have shifts ranging up to +3.7 . Carbon-13/carbon-12 values range from -2.6 to $-12.6 \%$. In this small set of samples, the hot springs are generally more depleted in carbon-13 than are the cold soda springs.

Many of the cold $\mathrm{CO}_{2}$-charged springs probably represent old hot-spring systems from which virtually all the heat has been dissipated. Fossil travertine near many of the $\mathrm{cold} \mathrm{CO}_{2}$-charged springs is an indication that the systems discharged hot water in the past. The low temperatures may indicate that all the heat has been discharged from the system or that the water movement is so slowed by minerals precipitated in the channels that all the heat is lost to the surrounding rock before the water discharges at the land surface. Differences observed in $\mathrm{C}-13 / \mathrm{C}-12$ values between the hot and cold $\mathrm{CO}_{2}$-charged waters may be produced by different rates of $\mathrm{CaCO}_{3}$ precipitation. Cold $\mathrm{CO}_{2}$-charged waters retain much more $\mathrm{CO}_{2}$ and therefore would precipitate less $\mathrm{CaCO}_{3}$ than the hot $\mathrm{CO}_{2}$-charged waters. Only two $18_{0} / 16_{0}$ values are available for dissolved sulfate in the thermal springs: Ohanapecosh $(+0.32 \%)$ and Garland $(+4.71 \%$ ) (Nehring and others, 1979). The sulfate $180 / 16_{0}$ values at Ohanapecosh and Garland hot springs are more depleted than marine sulfate $(+10 \%)$ but less depleted than values observed in high-temperature geothermal systems such as Lassen ( -3 to $-4 \% \circ)$. Carbon-14 values have been determined only for Longmire Mineral Spring $(1.78 \%$ modern $)$ and Garland Mineral Spring $(4.13 \%$ modern $)$.

\section{GEOTHERMOMETRY}

The chemical composition of thermal waters can be used to estimate the last temperature at which chemical equilibrium existed between the thermal water and the country rock. The variables that are most of ten used include 
Table 3. Compositions of gases discharging from srings in Washington [Compositions are in volume percent]

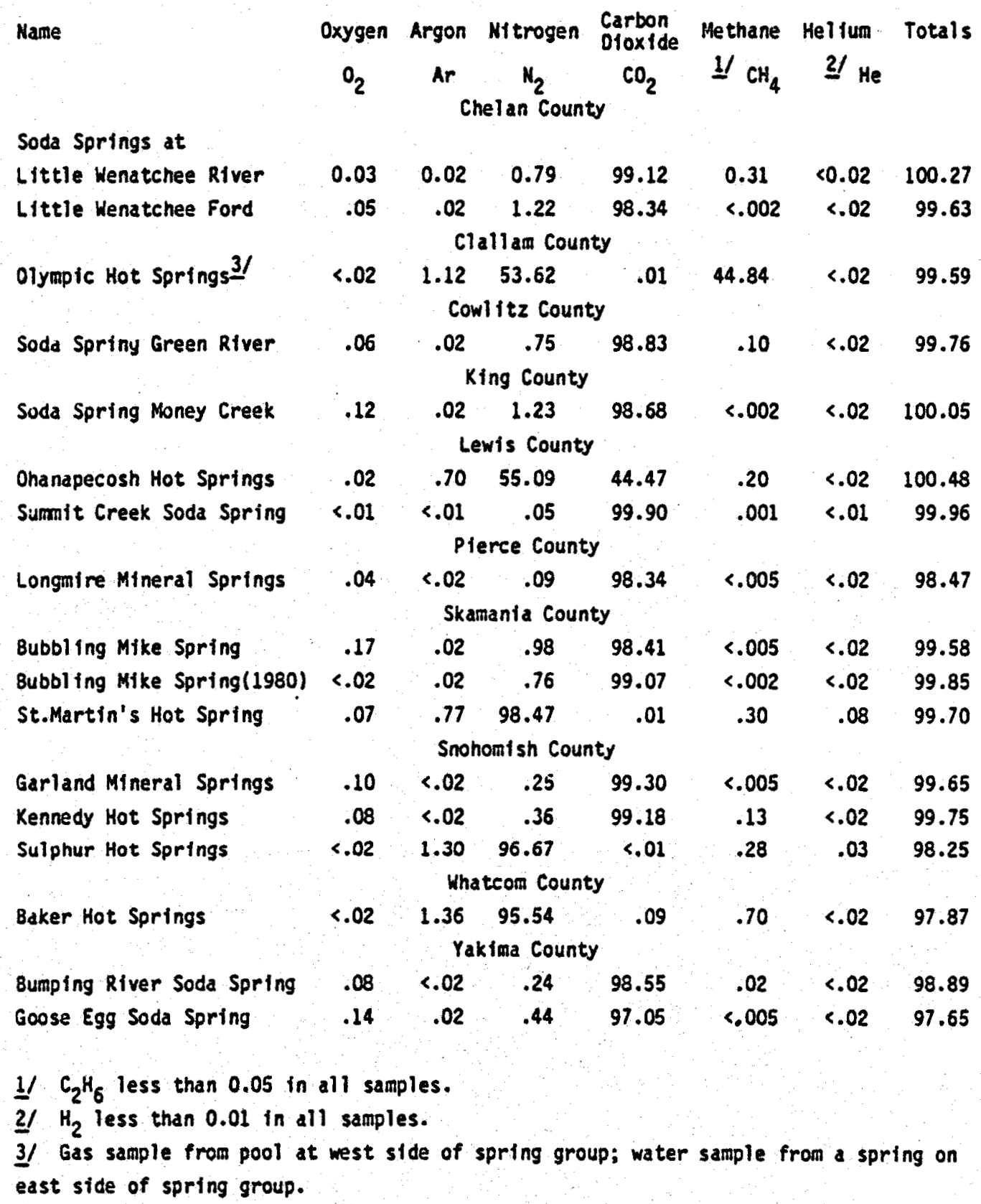


Table 4. Isotopic data for the springs of Wasnington [ Hydrogen and oxygen relative to SMOW; Carbon relative to PDB ]

Name

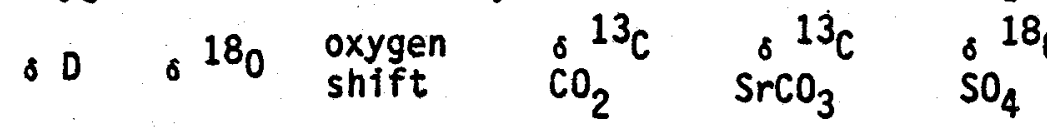

Chelan County

Soda Springs

$\begin{array}{llll}\text { Little Wenatchee River }-106.5 & -13.95 & +.61 & -9.32 \\ \text { Little Wenatchee Ford }-107.3 & -12.78 & +1.88 & -6.28\end{array}$

Clallam County

Olympic Hot Springs $\quad-95.8 \quad-13.32 \quad+.12$

Sol Duc Hot Springs $\quad-91.8 \quad-12.34 \quad+.39$

Cowl itz County

$\begin{array}{lllll}\text { Soda Spring Green River } & -83.5 & -11.39 & +.30 & -7.72\end{array}$

$\begin{array}{lrrr}\text { Goldmeyer Hot Spring } & -96.2 & -13.61 & -.34 \\ \text { Lester Hot Spring } & -99.0 & -13.41 & +.23 \\ \text { Scenic Hot Spring } & -103.4 & -14.32 & -.13\end{array}$

Money Creek Soda Spring

King County

Klickitat County

K1 ickitat Springs $\quad-111.1 \quad-14.45 \quad+.68 \quad-6.75$

Lewis County

$\begin{array}{lllllll}\text { Ohanapecosin Hot Springs } & -120.2 & -15.00 & +1.28 & -11.29 & +.32 \\ \text { Summit Creek. Soda Spring } & -96.6 & -11.83 & +1.50 & -12.23 & -9.48 & \end{array}$

Pierce County

Longmire Mineral Springs $-100.4 \quad-12.92 \quad+.86 \quad-13.50 \quad-10.77$

Skamania County

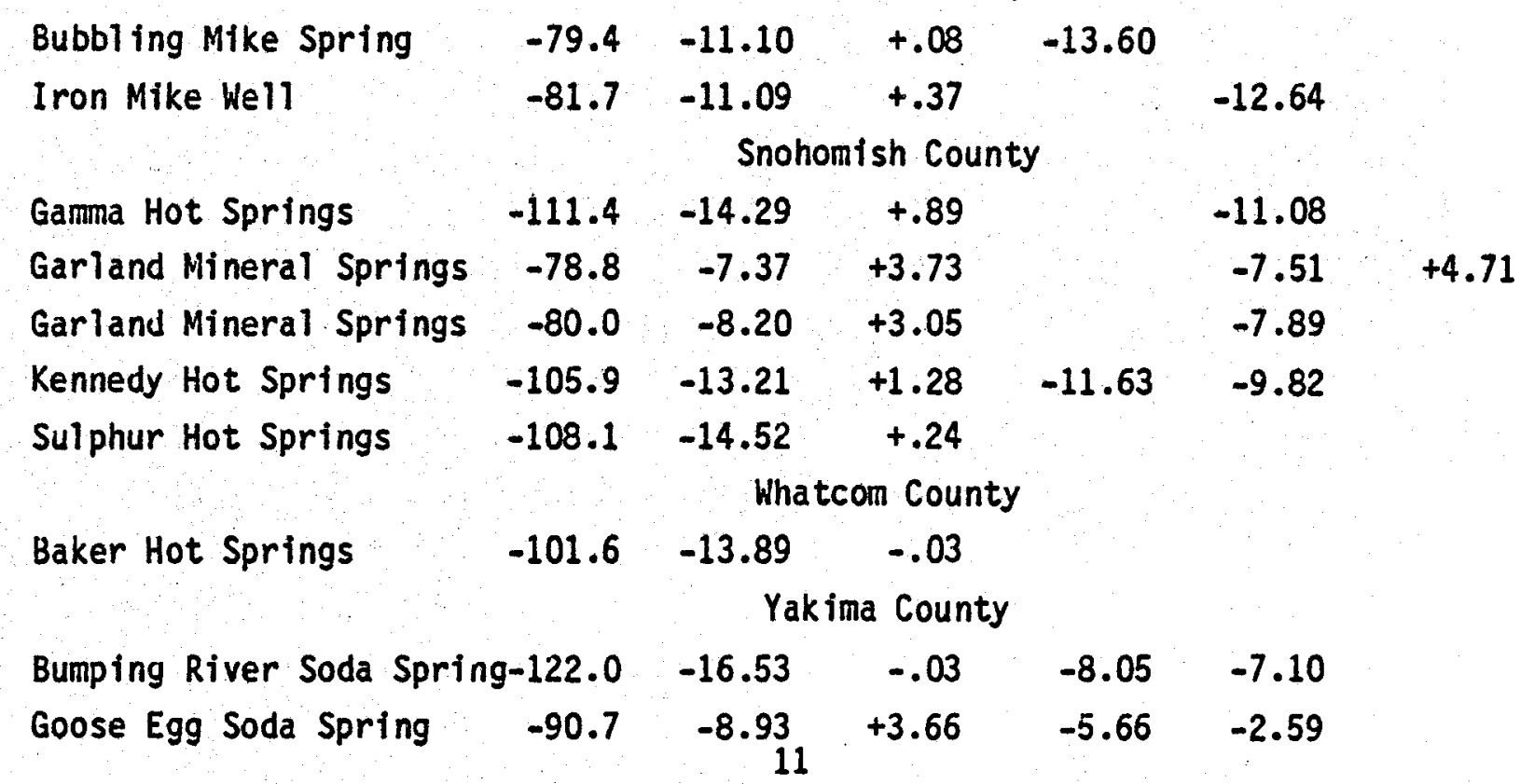


the silica concentration and the proportions of sodium, potassium, calcium, and magnesium. 0xygen-18/0xygen-16 distribution between dissolved suifate and water has also been used as an indicator of subsurface temperature in geothermal systems (McKenzie and Truesde11, 1977).

Temperatures estimated by geothermetric methods are valid only for hot-water systems and only when certain assumptions are true (Fournier and others, 1974). These assumptions are:

1. Temperature-dependent reactions at depth control the concentration of the consituents used in the geothermometer.

2. The reservoir contains an adequate supply of the reactants on which the geothermometer is based.

3. Water-rock equilibrium is established in the reservoir.

4. The constituents used in the geothermometer do not reequilibrate with the confining rock as the water flows to the surface.

5. Mixing of thermal and nonthermal ground water does not occur. Ideally, the concentration of dissolved silica in water depends on the temperature of the reservoir and the solubility of quartz. Practically, however, chalcedony rather than quartz limits dissolved-silica concentration in cooler systems, and the temperature at which chalcedony becomes the 1 imiting mineral depends not only on temperature but also on rock ty.pe (Arnorsson, 1975). For example, in granitic terrains, quartz limits dissolved silica concentrations to temperatures as low as 70 to $75^{\circ} \mathrm{C}$; in basaltic terrains, chalcedony limits dissolved silica concentrations to at least $120^{\circ} \mathrm{C}$ and possibly $180^{\circ} \mathrm{C}$. An additional complication is that the spring $\mathrm{pH}$ is higher than 8.5 in many granitic terrains, and at more alkaline $\mathrm{pH}^{\prime} \mathrm{s}$, the solubility of quartz or chalcedony is a function of both temperature and $\mathrm{pH}$ (Mariner and others, 1980).

Mixing of thermal (high-silica) and nonthermal (low-silica) waters can sharply reduce temperatures estimated from the silica geothermometer. If mixing can be demonstrated, then subsurface temperatures can be calculated using mixing models described by Fournier and Truesdell (1974). Unfortunately, the thermal springs of Wasinington generally occur as single springs or as small groups of springs that have the same chemical and isotopic composition. Temperature differences are generally minor within a group and are generally a function of flow rate. Mixing is possible in any of the thermal springs, but it has not been demonstrated by chloride-deuterium or chloride-temperature relationships. Mixing models therefore were not used. 
The $\mathrm{Na}-\mathrm{K}-\mathrm{Ca}$ and $\mathrm{Mg}$-corrected $\mathrm{Na}-\mathrm{K}-\mathrm{Ca}$ geothermometers are based on empirical relationships between the various cations and measured reservoir temperatures. Temperatures estimated from the cation geothermometers can be sharply increased by loss of calcium after the thermal fluid leaves the geothermal reservoir. Near-surface water-rock reaction with the country rock can release appreclable magnesium and can lead to excessively low temperatures estimated from the $\mathrm{Mg}$-corrected $\mathrm{Na}-\mathrm{K}$-Ca geothermometer.

As always, the chemical geothemometers should be used with caution and should be treated as indicators, not measurements. Generally, the $\mathrm{Na}-\mathrm{Cl}$ or dilute $\mathrm{Na}-\mathrm{HCO}_{3}$ waters are less reactive with the confining rock and undergo less change in chemical composition as the water moves from the reservoir to the surface. The $\mathrm{CO}_{2}$-charged waters give the least reliable geothermometry because of their reactive nature, either reacting with the country rock or precipitating $\mathrm{CaCO}_{3}$. Gamma, Baker, and Ohanapecosh hot springs are apparently associated with the highest temperature systems (table 5). Gamma Hot Springs has the highest estimated temperatures (quartz $=157^{\circ} \mathrm{C}$, and $\mathrm{Na}-\mathrm{K}-\mathrm{Ca}=216^{\circ} \mathrm{C}$ ); however, at Gamma, dilution is possible and precipitation of $\mathrm{CaCO}_{3}$ is probable. Not only is the water supersaturated with respect to $\mathrm{CaCO}_{3}$, but the dissolved carbon $\left({ }^{13} \mathrm{C} / 12 \mathrm{C}\right)$ composition is relatively depleted $(-11 \%)$. Thus the $\mathrm{Na}-\mathrm{K}-\mathrm{Ca}$ may indicate excessively high temperatures whereas the quartz geothermometer may indicate excessively low temperatures. Dilution may also effect Baker Hot Springs. Sulfate-water isotope geothermometer temperatures are not available for either Baker or Gamma Hot Springs. Ohanapecosh Hot Springs appears initially to be associated with an aquifer at a temperature of approximately $140^{\circ} \mathrm{C}$ on the basis of both quartz and $\mathrm{Mg}$-corrected $\mathrm{Na}-\mathrm{K}-\mathrm{Ca}$. However, sulfate-water isotope relationships indicate $110^{\circ} \mathrm{C}$, as does chalcedony. In addition, the water is supersaturated with $\mathrm{CaCO}_{3}$ and is relatively depleted in carbon-13 ${ }_{0}{ }^{13} \mathrm{C} /{ }^{12} \mathrm{C}=-12$ $\% \circ)$. Therefore, it appears that $\mathrm{CaCO}_{3}$ has been lost from the solution as it moved from the reservoir to the surface. The most probable equilibrium temperature at ohanapecosh is $110^{\circ} \mathrm{C}$. Higher temperatures than those indicated from the silica or Na-K-Ca geothermometers are possible in some of the $\mathrm{CO}_{2}$-charged waters. For instance, Garland Mineral Springs $129^{\circ} \mathrm{C}$ at the surface) has an indicated sulfate-water isotopic equilibrium temperature of $149^{\circ} \mathrm{C}$. The high concentration of dissolved silica in the cooler $\mathrm{CO}_{2}$-charged waters probably is a function of the rate of silica mineral dissolution and is not controlled by equilibrium with quartz or chalcedony at elevated 
Table 5. Aquifer-temperature estimates for selected springs and wells in Washington [ Temperatures are reported in degrees Celsius $\left({ }^{\circ} \mathrm{C}\right)$ ]

Name Spring Quartz Chalcedony $\mathrm{Na}-\mathrm{K}$ Na-K- $\mathrm{Na}-\mathrm{K}-$ Chelan County

Soda Springs at

Little Wenatchee River 7

Little Wenatchee Ford 9

Olympic Hot Springs

Sol Duc Hot Springs

Soda Spring Green R. $\quad 16$

Goldmeyer Hot Spring

Lester Hot Spring

Scenic Hot Spring

Klickitat Springs

23

Ohanapecosh Hot Spring 48

Summit Creek Soda Spr. 11

Longmire Mineral Spr. 19

Iron Mike Well 18

St.Martin's Hot Spring 48 Bonneville Hot Spring 36

Gamma Hot Springs

Garland Mineral Spring

Kennedy Hot Springs $\quad 35$

Sulphur Hot Springs 37

Baker Hot Springs

Bumping River Soda Spr. 9

Goose Egg Soda Spring 10

51

50

47

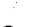

44

91

140

48.5

46.5

3

.

9

8

8

36

65

35

37

139

114
100
70

115

111

Cowl itz County

136

109

$154 \quad 15$

$141 \quad 153$

105

81

Clallam County

$\begin{array}{lll}200 & 19 & 89\end{array}$

$$
\text { King County }
$$

102

$$
65
$$

$92 \quad 118$

87

100

56

$81 \quad 108$

75

65

42

6590

52

Kifckitat County

139$$
112
$$

193

159

48

7

Lewis County

137

110

$172 \quad 171$

172

140

137

110

110162 .

161

42

Pierce County

150

125

$159 \quad 161$

96

46

Skamania County

$114 \quad 86$

$87 \quad 105$

57

53

$\quad 70$

$78 \quad 104$

69

89

Snohomish County

$\begin{array}{rr}157 & 133 \\ 140 & 114 \\ 171 & 149 \\ 105 & 65\end{array}$

133

$210 \quad 216$

178

196

114

$160 \quad 190$

196

80

149

$181 \quad 189$

145

68

Whatcom County

$\begin{array}{lll}81 & 117 & 108\end{array}$

39

Yakima County

134

$$
107
$$

105

$138 \quad 162$

140

162

133

$\begin{array}{rrr}79 & 92 & 32 \\ 111 & 121 & 60 .\end{array}$

23 
temperatures. In the coldest $\mathrm{CO}_{2}$-charged soda springs, saturation with respect to amorphous silica is approached. Initially, it appears that the quartz geothermometer indicates higher reservoir temperatures than the $\mathrm{Na}-\mathrm{K}-\mathrm{Ca}$ geothermometer in the dilute alkal ine waters that discharge at $01 y$ mpic, Sol Duc, Sulfur, Bonneville, Goldneyer, Lester, and Scenic hot springs. However, the solubility of quartz or chalcedony in waters as alkaline as these is a function of both temperature and $\mathrm{pH}$. Using one of the solution-mineral computer models such as SOLMNEQ (Kharaka and Mariner, 1977) or ENTHALP (Truesde11 and Singers, 1974) it is possible to estimate aquifer pH at sucessively higher temperatures and to determine theoretical equilibrium temperatures between quartz or chalcedony and the respective waters. These estimated temperatures agree more closely with the temperatures estimated from the $\mathrm{Na}-\mathrm{K}-\mathrm{Ca}$ geothermometer. Sulphur Hot Springs discharges the only dilute alkaline water that seems to be associated with an aquifer at temperatures of more than $100^{\circ} \mathrm{C}\left(110^{\circ}\right.$ to $\left.117^{\circ} \mathrm{C}\right)$.

\section{DISCUSSION}

Although the thermal springs of Washington are associated with an area of young volcanic activity, the chemical data do not indicate the presence of numerous high temperature geothermal systems. Baker Hot Springs and Gamma Hot Springs appear to have the highest temperatures (at least $150^{\circ} \mathrm{C}$ ). Baker Hot Springs appears to be the only system with development potential. The system may have an aquifer temperature of more than $150^{\circ} \mathrm{C}$, but it may also be small. Gamna and Ohanapecosh, two of the highest temperature systems, are in wilderness areas or National Parks and are not available for development. Sulphur Hot Springs has an estimated aquifer temperature of only slightly more than $100^{\circ} \mathrm{C}$; the low discharge rate, apparently restricted size, isolated location, and moderate temperature, all combine to produce a system of minor importance. All other systems appear to be associated with reservoirs of $115^{\circ} \mathrm{C}$ or less.

A problem which we have not addressed is the origin of the carbon dioxide in the $\mathrm{CO}_{2}$-charged waters. Temperatures indicated by the geothermometers for these waters are totaliy inadequate to explain the generation of the amounts of $\mathrm{CO}_{2}$ discharged in the springs. The $\mathrm{CO}_{2}$ is may be generated in the lower crust or upper mantle (Barnes and others, 1978). This $\mathrm{CO}_{2}$ of deep origin could be dissolved in deeply circulating thermal waters. Variations in the carbon isotopic composition of the dissolved $\mathrm{CO}_{2}$ in the respective 
spring water is probably due to reaction with near-surface 1 imestone; to isotopic equilibration with the 1 imestone if residence times are long enough;

or to isotopic depletion if $\mathrm{CaCO}_{3}$ is precipitated from the water as it migrates from depth to the land surface. 


\section{REFERENCES CITED}

American Society for Testing and Materials, 1974, Annual Book of A.S.T.M. Standards, part 31, [Water]: Philadelphia, Pa., p. 275-276.

Arnorsson, Stefan, 1975, Application of the silica geothermometer in low temperature hydrothermal areas in Iceland: American Journal of Science, v. 275 , p. $763-784$.

Barnes, Ivan, Irwin, W. P., and White, D. E., 1978, Glodal distribution of carbon dioxide discharges, and major zones of seismicity: U.S.Geological Survey Water-Resources Investigations 78-39, 12 p.

Barnes, Ivan, Johnston, D. A., Evans, W. C., Presser, T. S., Mariner, R. H., and White, L. D., 1981, Properties of gases and waters of deep origin near Mount. St Helens: U.S. Geological Survey Professional Paper 1250 (in press).

Berry, G. W., Grimm, P. J., and Ikelman, J. A., compilers, 1980, Thermal spring 1 ist for the United States: National Oceanic and Atmospheric Administration, Key to Geophysical Records Documentation No. 12, 59 p.

Bigeleisen, Jacob, Perlman, M. L., and Prosser, H. C., 1952, Conversion of hydrogenic materials to hydrogen for isotope analysis: Analytical Chemistry, v. 24, p. 1356-1357.

Cohn, Mildred, and Urey, H.C., 1938, Oxygen exchange reactions of organic compounds and water: American Chemical Society Journal, v. 60, p. 679.

Fournier, R. 0., 1973, Silica in thermal waters: Laboratory and field investigations, in Clark, J. W., ed., Proceedings of International Symposium on Hydrogeochemistry and Biogeochemistry, Japan, 1970, Vol ume 1, Hydrogeochemistry: Washington, D.C., p. 122-139.

Fournier, R. 0., and Potter, R. W., II, 1978, A magnesium correction for the $\mathrm{Na}-\mathrm{K}-\mathrm{Ca}$ geothemometer: Geochimica et Cosmochimica Acta, v. 43, p. 1543-1550.

Fournier, R. 0., and Rowe, J. J., 1966, Estimation of underground temperatures from the silica content of water from hot springs and wet-steam wells: American Journal of Science, $v$. 264, p. 685-697.

Fournier, R. 0., and Truesde11, A. H., 1973, An empirical Na-K-Ca geothermometer for natural waters: Geochemica et Cosmuchimica Acta, v. 37, p. 1255-1275.

Fournier, R. 0., and Truesdell, A. H., 1974, Geochemical indicators of subsurface temperature and fraction of hot water mixed with cold water: U.S. Geological Survey Journal of Research, v. 2, no. 3, p. 263-270.

Fournier, R. 0., White, D. E., and Truesde11, A. H., 1974, Geochemical indicators of subsurface temperature-part 1, basic assumptions: U.S. Geological Survey Journal of Research, v. 2, no. 3, p. 259-262. 
Gleason, J. D., Friedman, Irving, and Hanshaw, B. B., 1969, Extraction of dissolved carbonate species from natural water for carbon-isotope analysis: U.S. Geological Survey Professional Paper 650-D, P. D248-D250.

Griggs, A. B., 1966, Columbla Basin in Mineral and Water Resources of Washington: Washington, D.C., U.S. Government Printing Office, p. 22-27.

Kharaka, Y. K., and Mariner, R. H., 1977, Solution-mineral equilibrium in natural water-rock systems: Proceedings of the Second International Symposium on Water-Rock Interaction, Strasbourg, August 17 to 25, 1977, p. 66-75.

McCrea, J.M., 1950, On the isotopic chemistry of carbonates and a paleotemperature scale: Journal of Chemical Physics, v. 18, p. 849-857.

McKenzie, W. F., and Truesdel1, A. H., 1977, Geothermal reservoir temperatures estimated from the oxygen isotopic compositions of dissolved sulfate and water from hot springs and shallow drill-holes: Geothermics, v. 5, p. 51-61.

Mariner, R. H., Swanson, J. R., Orris, G. J., Presser, T. S., and Evans, W. C., 1980, Chemical and isotopic data for water from thermal springs and wells of Oregon: U.S. Geological Survey Open-File Report 80-737, 50 p.

Nehring, N. L., Mariner, R. H., White, L. D., Huebner, M. A., Roberts, E. D., Harmon, Karen, Bowen, P. A., and Tanner, Lane, 1979, -Sulfate geothermometry of thermal waters in the western United States: U.S. Geological Survey Open-File Report 79-1135, 11 p.

Presser, T. S., and Barnes, Ivan, 1974, Special techniques for determining chemical properties of geothermal water: U.S. Geological Survey Water-Resources Investigations $22-74,11 \mathrm{p}$.

Skougstad, M. W., Fishman, M. J., Friedman, L. C., Erdmann, D. E., and Duncan, S. S., 1979, Methods for the determination of inorganic substances in water and fluvial sediments: U.S. Geological Survey Techniques of Water Resources Investigations, Book 5, Chapter A1, 626 p.

Truesde11, A. H., and Singers, Wendy, 1974, The calculation of aquifer chemistry in hot-water geothermal systems: U.S. Geological Survey Journal of Research v. 2, no. 3, p. 271-278.

U. S. Environmental Protection Agency, 1971, Methods for chemical analys is of water and wastes: Washington, U.S. Government Printing Office, p. 121-130.

Wagner, H. C., and Snavely, P. D., Jr., 1966, Western Washington, in Mineral and Water Resources of Washington: Washington, D.C., U.S. Government Printing office, p. 37-46.

Weissenborn, A. E., and Cates, F. W., 1966, The Cascade Mountains, in Mineral and Water Resources of Washington: Washington, D.C., U.S. Government Printing Office, p. 27-36. 